\title{
Mechanical and Oxidation Properties of Cold-Rolled Zr-Nb-O-S Alloys
}

\author{
Jong-Min Lee, A. J. Nathanael, Pyung-Woo Shin*, Sun Ig Hong ${ }^{\dagger}$ and Yong Hwan Jeong** \\ Department of Nanomaterials Engineering Chungnam National University, Daejon \\ *Department of Metallurgy and Materials Engineering, Changwon National University, Changwon \\ **Department of Applied Nuclear Technology Development, Korea Atomic Energy Research Institute, Daejon
}

(Received December 27, 2010 : Received in revised form January 27, 2011 : Accepted January 28, 2011)

\begin{abstract}
The stress-strain responses and oxidation properties of cold-rolled $\mathrm{Zr}-1.5 \mathrm{Nb}-\mathrm{O}$ and $\mathrm{Zr}-1.5 \mathrm{Nb}-\mathrm{O}-\mathrm{S}$ alloys were studied. The U.T.S. (ultimate tensile strength) of cold-rolled Zr-1.5Nb-O-S alloy with 160 ppm sulfur (765 MPa) were greater than that of $\mathrm{Zr}-1 \mathrm{Nb}-1 \mathrm{Sn}-0.1 \mathrm{Fe}$ alloy $(750 \mathrm{MPa})$, achieving an excellent mechanical strength even after the elimination of $\mathrm{Sn}$, an effective solution strengthening element. The addition of sulfur increased the strength at the expense of ductility. However, the ductile fracture behavior was observed both in $\mathrm{Zr}-\mathrm{Nb}-\mathrm{O}$ and $\mathrm{Zr}-\mathrm{Nb}-\mathrm{O}-\mathrm{S}$ alloys. The beneficial effect of sulphur on the strengthening was observed in the cold rolled $\mathrm{Zr}-1.5 \mathrm{Nb}-\mathrm{O}-\mathrm{S}$ alloys. The activation volume of cold-rolled $\mathrm{Zr}-1.5 \mathrm{Nb}$ decreased with sulfur content in the temperature region of dynamic strain aging associated with oxygen atoms. Insensitivity of the activation volume to the dislocation density and the decrease of the activation volume at a higher temperature where the dynamic strain aging occurs support the suggestion linking the activation volume with the activated bulge of dislocations limited by segregation of oxygen and sulfur atoms. The addition of sulfur was also found to improve the oxidation resistance of $\mathrm{Zr}$ $\mathrm{Nb}-\mathrm{O}$ alloys.
\end{abstract}

Key words strength, ductility, oxidation, weight gain, fracture.

\section{Introduction}

$\mathrm{Zr}$ alloys have been used as nuclear cladding materials since it has shown high temperature strength, corrosion resistance, good mechanical properties, and low neutron absorption. ${ }^{1)} \mathrm{Zr}$ alloys' in-reactor behaviors such as corrosion, mechanical strength, creep and irradiation- induced growth are mainly controlled by its alloying elements and thermo-mechanical processing during pilgering. ${ }^{2-4)}$ The first generation zirconium alloys such as Zircaloy-2 and Zircaloy-4 contain alloying elements such as $\mathrm{Sn}, \mathrm{Fe}$ and $\mathrm{Cr}$ and have been used for several decades in the nuclear reactors without any significant performance problems. The efforts to enhance the safety and economy of nuclear power plants, however, have led to the development of the second generation $\mathrm{Zr}$ alloys such as $\mathrm{Zirlo}^{\mathrm{TM}}$ (trademark of Westinghouse Electric Co.), M5TM (trademark of AREVANP), and other $\mathrm{Zr}$ alloys.

The important alloying elements in Zirlo ${ }^{\mathrm{TM}}(\mathrm{Zr}-\mathrm{Nb}-\mathrm{Sn}-\mathrm{Fe}$ base alloy) and $\mathrm{M}^{\mathrm{TM}}$ ( $\mathrm{Zr}-\mathrm{Nb}$ base alloy) tubes are $\mathrm{Nb}$ and $\mathrm{Sn}$. Based on in-reactor experience of various $\mathrm{Zr}$ alloys, it is generally found that $\mathrm{Sn}$ increases the mechanical strength and creep resistance but decrease the corrosion resistance, ${ }^{4,5}$ while $\mathrm{Nb}$ increases the corrosion and irradiation-induced

${ }^{\dagger}$ Corresponding author

E-Mail : sihong@cnu.ac.kr (S. I. Hong) growth resistance. ${ }^{4)}$ It was also found that the higher heat treatment temperature after the final pilgering step lowered the mechanical strength but enhanced the corrosion and growth resistance. ${ }^{5)}$ Therefore, stress relieved claddings may be favored if relatively higher mechanical strength is required, while fully recrystallized cladding is favored if better corrosion and growth resistance are needed. ${ }^{4,5)}$

One interesting and surprising observation in $\mathrm{Zr}$ base alloys is that the addition of sulphur as little as $25 \mathrm{ppm}$ enhanced the mechanical strength, creep resistance and corrosion resistance. ${ }^{6,7)}$ Sulfur and phosphorus have been known to cause the embrittlement in many alloys by reducing the boundary cohesive strength. ${ }^{8-10)}$ A surprising result that the thermal creep resistance can be improved drastically by the addition of sulfur ${ }^{9)}$ has almost been unnoticed outside the nuclear industry and the nuclear-related academic community. The addition of $25 \mathrm{wt} \% \mathrm{ppm}$ sulfur is known to be enough to reduce the creep rate of zirconium alloys by a factor of three at $400^{\circ} \mathrm{C}$. $^{9,10)}$ Charquet $^{11)}$ also reported that sulfur has an extremely beneficial effect on the steam corrosion resistance in zirconium alloys at $400^{\circ} \mathrm{C}$. Sulfur containing zirconium alloys have been patented ${ }^{10,12)}$ and commercialized.

$\mathrm{Zr}-\mathrm{Nb}$ base alloys are known to have a better corrosion resistance, but a lower creep resistance than $\mathrm{Zr}-\mathrm{Nb}-\mathrm{Sn}-\mathrm{Fe}$ alloys. Recent observation that the creep resistance and the tensile strength enhanced with the addition of small 
Table 1. Chemical compositions of $\mathrm{Zr}-1.5 \mathrm{Nb}$ and $\mathrm{Zr}-1.5 \mathrm{Nb}-\mathrm{P}$ - alloys (by weight).

\begin{tabular}{cccccc}
\hline & $\mathrm{Nb}(\%)$ & $\mathrm{Fe}(\mathrm{ppm})$ & $\mathrm{O}(\mathrm{ppm})$ & $\mathrm{S}(\mathrm{ppm})$ & $\mathrm{Zr}$ \\
\hline $\mathrm{Zr}-1.5 \mathrm{Nb}$ & 1.53 & 253 & 1520 & $<5$ & balance \\
$\mathrm{Zr}-1.5 \mathrm{Nb}-\mathrm{O}-25 \mathrm{ppm} \mathrm{P}$ & 1.48 & 336 & 1570 & 23 & balance \\
$\mathrm{Zr}-1.5 \mathrm{Nb}-\mathrm{O}-160 \mathrm{ppm} \mathrm{P}$ & 1.55 & 523 & 1580 & 156 & balance \\
\hline
\end{tabular}

amount of sulfur may lead to the improved $\mathrm{Zr}-\mathrm{Nb}$ base alloys. Ferrer et al. ${ }^{6)}$ observed that sulfur amplified many dynamic strain aging effects reputed to be due to oxygen, the yield stress plateau, the strain rate sensitivity and ductility minimum, and the static aging peak. Chang and Hong $^{7)}$ suggested that the deformation and strengthening mechanism for the deformation of $\mathrm{Zr}-\mathrm{Nb}-\mathrm{O}$ and $\mathrm{Zr}-\mathrm{Nb}-$ O-S alloys can best be explained by the dislocation interaction mechanism in which the segregation of alloying elements which affects the activation length of dislocations. ${ }^{9)}$

In this study, cold-rolled $\mathrm{Zr}-1.5 \mathrm{Nb}-\mathrm{O}-\mathrm{S}$ alloys for better mechanical strength and corrosion resistance were designed and their properties were characterized. Since $\mathrm{Zr}-1 \mathrm{Nb}-\mathrm{O}$ alloys have the lower creep resistance than $\mathrm{Zr}-1 \mathrm{Nb}-0.8 \mathrm{Sn}-$ $0.1 \mathrm{Fe}$ alloys, $\mathrm{Zr}-1.5 \mathrm{Nb}$ alloys alloyed with higher $\mathrm{Nb}$ and oxygen contents and a small amount of sulfur content ( $\mathrm{Zr}$ $1.5 \mathrm{Nb}-\mathrm{O}-\mathrm{S}$ alloys) were used for enhanced mechanical performance. The increase of $\mathrm{Nb}$ content to $1.5 \mathrm{wt}$. \%, which is higher than that of the typical $\mathrm{Zr}-1 \mathrm{Nb}-\mathrm{O}$ cladding tube alloys and the oxygen content to $1570 \sim 1610 \mathrm{ppm}$, which is close to the higher end of the typical oxygen content in commercial $\mathrm{Zr}$ alloys, are expected to enhance the creep resistance and the mechanical strength. The higher oxygen content is also thought to induce more significant amplified effect of sulfur on the oxygen strengthening. The primary objective of this study is to investigate the deformation and fracture behaviors of $\mathrm{Zr}-1.5 \mathrm{Nb}-\mathrm{O}-\mathrm{S}$ alloys and compare them to those of commercially available $\mathrm{Zr}$ alloys for nuclear fuel claddings such as $\mathrm{Zr}-1 \mathrm{Nb}-1 \mathrm{Sn}-0.1 \mathrm{Fe}$ alloy.

\section{Experimental Procedure}

$\mathrm{Zr}-1.5$ wt. \% Nb-O alloys without and with various sulfur contents $(25 \mathrm{ppm}, 160 \mathrm{ppm})$ were cast by vacuum arc melting. The addition of sulfur was made by adding iron sulfide in the melt. The chemical compositions of $\mathrm{Zr}$ $1.5 \mathrm{Nb}-\mathrm{O}$ and $\mathrm{Zr}-1.5 \mathrm{Nb}-\mathrm{O}-\mathrm{S}$ alloys are summarized in Table 1. The disk-shaped ingots ( $15 \mathrm{~mm}$ thick) were $\beta$-quenched (maintained at $1020^{\circ} \mathrm{C}$ for $0.5 \mathrm{hr}$ and quenched to water at room temperature), hot-rolled at $580^{\circ} \mathrm{C}$, annealed at $580^{\circ} \mathrm{C}$ for $3 \mathrm{hrs}$. and cold-rolled into $0.9 \mathrm{~mm}$ thick plates with 3 intermediate heat treatments at $570^{\circ} \mathrm{C}$ for $2 \mathrm{hrs}$. During the final cold rolling process, the thickness of plates was reduced from $1.76 \mathrm{~mm}$ to $0.90 \mathrm{~mm}$.
Tensile testing was performed with the stress axis parallel to the rolling direction using a united testing machine (SFP 10). Strain jump tests were performed at room temperature and $300^{\circ} \mathrm{C}$ to obtain the strain rate sensitivity. In strain jump tests, the samples were initially strained at the strain rate of $10^{-4} / \mathrm{sec}$ and the strain rate was changed to $10^{-2} / \mathrm{sec}$ at the plastic strain of 0.025 . Oxidation tests were performed at $300^{\circ} \mathrm{C}$ in air.

\section{Results and Discussion}

Fig. 1 displayed the TEM micrograph of cold rolled $\mathrm{Zr}-$ 1.0Nb-O. The cold rolled $\mathrm{Zr}-1.5 \mathrm{Nb}-\mathrm{O}$ has the featureless high dislocation density with the bending contours contours, which resulted from the locally accumulated strain fields of dislocations in the cold rolled alloys. The cold rolled $\mathrm{Zr}-1.5 \mathrm{Nb}-\mathrm{O}$ with the addition of sulfur also has the featureless high dislocation density with the bending contours. which is similar to that of $\mathrm{Zr}-1.5 \mathrm{Nb}$ and will not be shown in this paper. As shown in Fig. 2, X-ray diffraction pattern analysis on $\mathrm{Zr}-1.5 \mathrm{Nb}-\mathrm{O}$ and $\mathrm{Zr}-1.5 \mathrm{Nb}-\mathrm{O}-\mathrm{S}$ did not

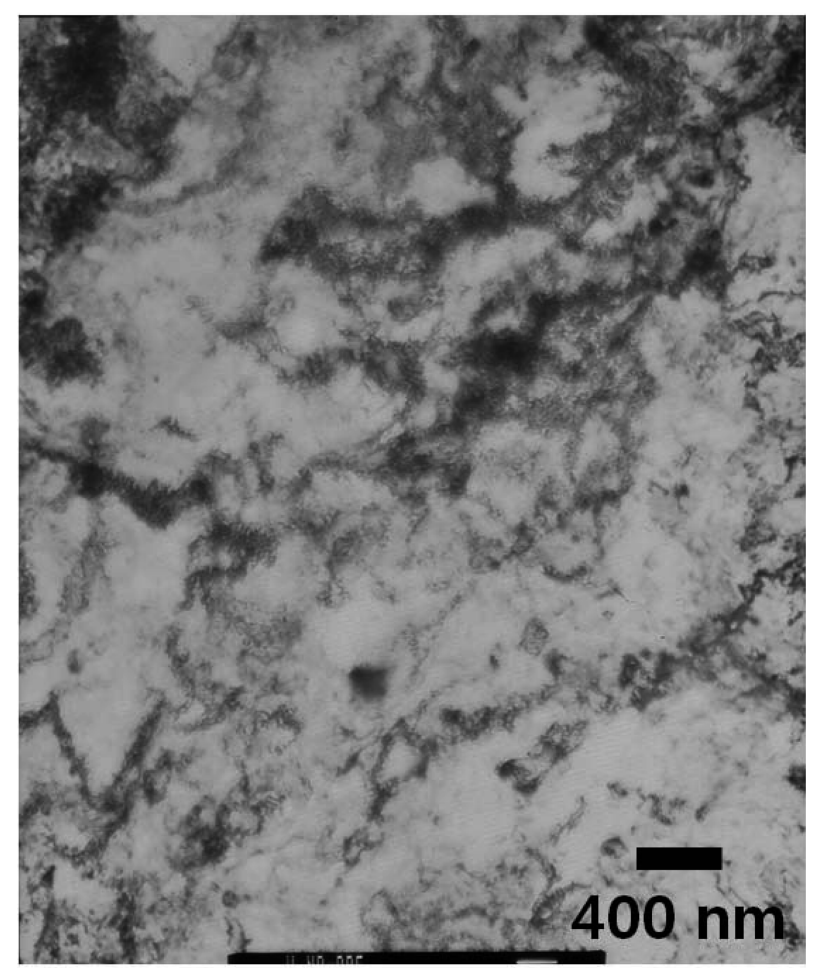

Fig. 1. TEM micrograph of cold rolled $\mathrm{Zr}-1.5 \mathrm{Nb}-\mathrm{O}$. 


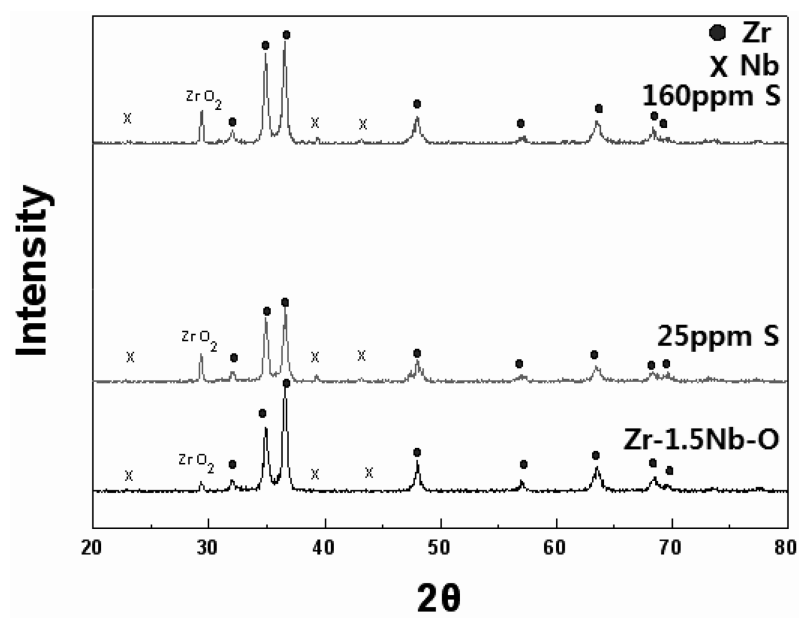

Fig. 2. X-ray diffraction pattern analysis on $\mathrm{Zr}-1.5 \mathrm{Nb}-\mathrm{O}$ and $\mathrm{Zr}$ $1.5 \mathrm{Nb}-\mathrm{O}-\mathrm{S}$ did not display any peak from sulfur containing compounds such as iron sulfide, zirconium sulfide and niobium sulfide.

display any peak from sulfur containing compounds such as iron sulfide, zirconium sulfide and niobium sulfide, which is likely due to the low sulfur. Fig. 3(a), 3(b) and 3(c) show the EDS spectra from $\mathrm{Zr}$ matrix (a) rod-shaped particle (b) and round particles (c). EDS analysis revealed that small round particles in Fig. 1 are Fe containing intermetallics and rod-shaped particles are $\beta-\mathrm{Nb}^{13)}$

The increase of strength with sulfur addition may be linked to the increase of the solution strengthening of sulfur and dislocation density. The increase of dislocation density can be caused by either the increase of statistically stored dislocation due to a lower recovery rate or that of geometrically necessary dislocation due to the presence of large particles. Since the population of intermetallic particles is not much influenced by the addition of sulfur, the increase of dislocation density with a higher sulfurcontent can be associated with the increase of statistically stored dislocation due to a lower recovery rate. The recovery rate is dependent on the alloying content since the alloying content influence the stacking fault energy and cross slip and climb of dislocations are influenced by the stacking fault energy.

The stress strain responses of cold-rolled $\mathrm{Zr}-1.5 \mathrm{Nb}-\mathrm{O}$ without and with sulfur contents ( $25 \mathrm{ppm}$ and $160 \mathrm{ppm}$ ) at room temperature and $300^{\circ} \mathrm{C}$ are shown in Fig. 4. The flow stress of cold-rolled $\mathrm{Zr}-1.5 \mathrm{Nb}-\mathrm{O}$ increased by $\sim 135$ $\mathrm{MPa}$ at room temperature with the addition of $25 \mathrm{ppm}$ sulfur. With further increase of sulfur content up to 160 ppm, a slight increase of the flow stress was observed. In the cold rolled $\mathrm{Zr}-1.5 \mathrm{Nb}-\mathrm{O}$ and $\mathrm{Zr}-1.5 \mathrm{Nb}-\mathrm{O}-\mathrm{S}$ alloys, flow softening is dominant after the peak stress. The high strength and the dominant flow softening after initial brief strengthening reflect the higher stored cold work during
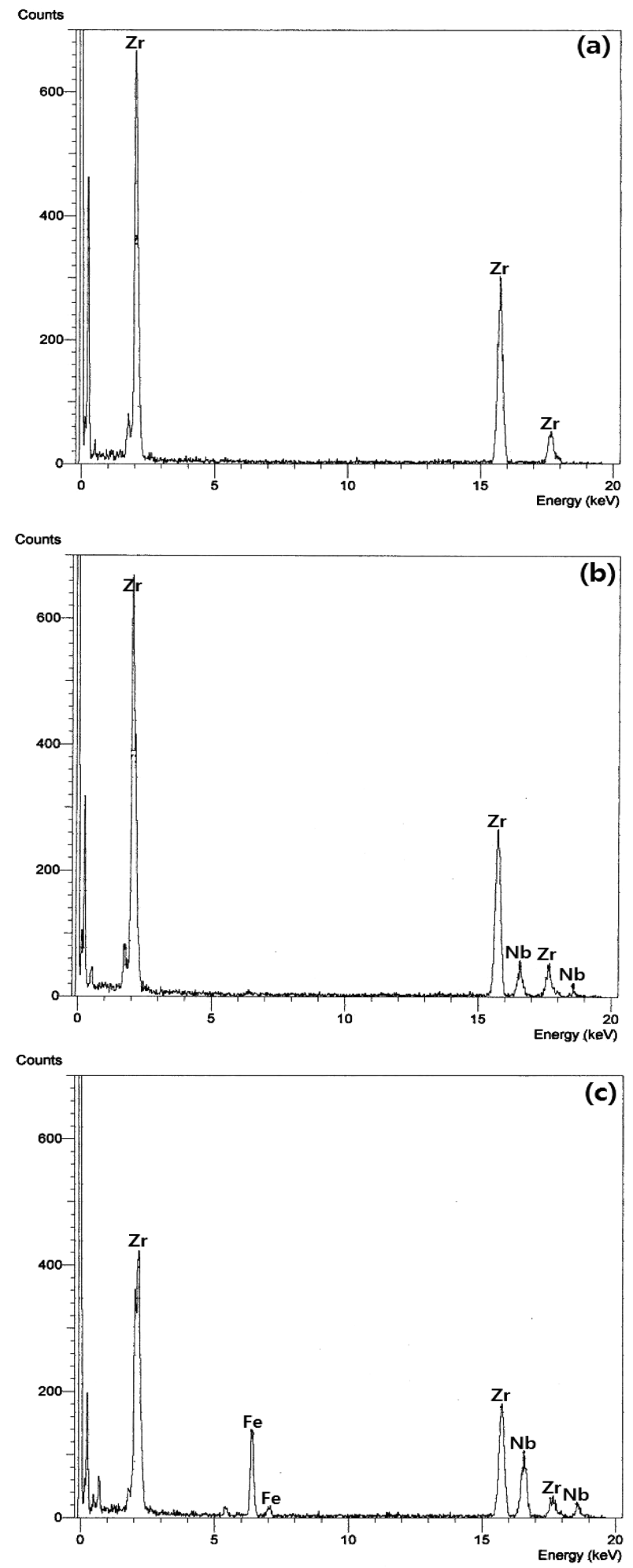

Fig. 3. EDS spectra from $\mathrm{Zr}$ matrix (a), rod-shaped particle (b) and round particles (c). EDS analysis revealed that small round particles are $\mathrm{Fe}$ containing intermetallics and rod-shaped particles are $\beta-\mathrm{Nb}$.

the thermo-mechanical processing. No yield drops were observed in the cold rolled alloys because the substructure strengthening due to the high dislocation density is far 


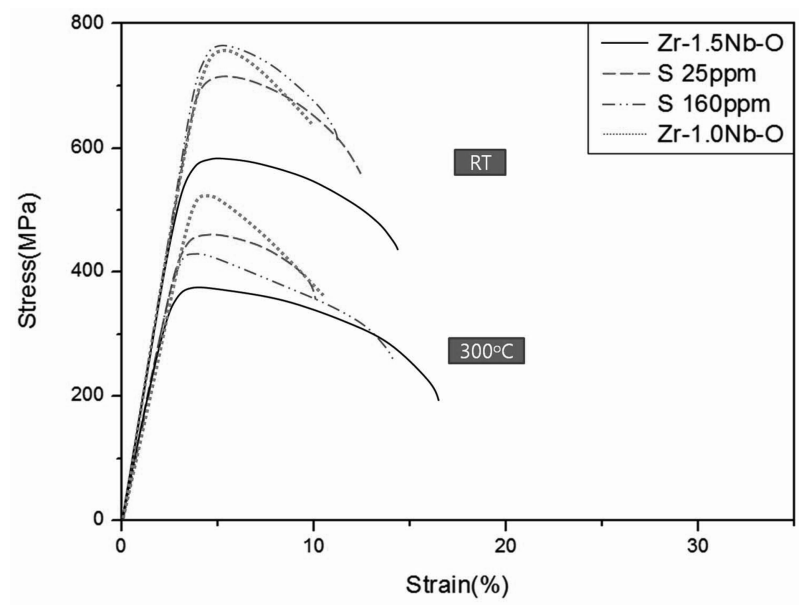

Fig. 4. Stress strain responses of cold rolled $\mathrm{Zr}-1.5 \mathrm{Nb}-\mathrm{O}, \mathrm{Zr}-1.5 \mathrm{Nb}-$ $\mathrm{O}-25 \mathrm{ppm} \mathrm{S}, \mathrm{Zr}-1.5 \mathrm{Nb}-\mathrm{O}-160 \mathrm{ppm} \mathrm{S}$ and $\mathrm{Zr}-1.0 \mathrm{Nb}-\mathrm{O}$ at the strain rate of $1 \times 10^{-4} / \mathrm{sec}$ at room temperature and $300^{\circ} \mathrm{C}$.

greater than the dynamic strain aging effect. The room temperature yield strength of $\mathrm{Zr}-1.5 \mathrm{Nb}-\mathrm{O}(570 \mathrm{MPa})$ was observed to be lower than that of $\mathrm{Zr}-1 \mathrm{Nb}-1 \mathrm{Sn}-0.1 \mathrm{Fe}$ $(710 \mathrm{MPa})$, a commercially available nuclear cladding alloy, but the yield strengths of $\mathrm{Zr}-1.5 \mathrm{Nb}-\mathrm{O}-\mathrm{S}$ alloy with 160 ppm sulfur ( $740 \mathrm{MPa}$ ) were higher than that of $\mathrm{Zr}-1 \mathrm{Nb}$ $1 \mathrm{Sn}-0.1 \mathrm{Fe}$ alloy $(730 \mathrm{MPa})$, achieving higher strength than $\mathrm{Zr}-1 \mathrm{Nb}-1 \mathrm{Sn}-0.1 \mathrm{Fe}$ alloy even after the elimination of Sn, an effective solution hardening alloying element. The ductility of $\mathrm{Zr}-1.5 \mathrm{Nb}-\mathrm{O}-\mathrm{S}$ was found to be higher compared to that of commercially available $\mathrm{Zr}-1 \mathrm{Nb}-1 \mathrm{Sn}-0.1 \mathrm{Fe}$. At $300^{\circ} \mathrm{C}$, the flow stress also increased, but by a smaller amount $\sim 90 \mathrm{MPa}$ with the addition of $25 \mathrm{ppm}$ sulphur and no appreciable change of the flow stress was observed with further increase of sulphur. The ductility did not increase appreciably up to $300^{\circ} \mathrm{C}$ because of the dynamic strain aging at $200 \sim 400^{\circ} \mathrm{C}$ and began to increase rapidly above $400^{\circ} \mathrm{C}$.

Strain rate jump tests were performed to investigate the effect of strain rate in the cold rolled $\mathrm{Zr}-1.5 \mathrm{Nb}-\mathrm{O}$ and $\mathrm{Zr}$ $1.5 \mathrm{Nb}-\mathrm{O}-\mathrm{S}$ alloys and stress-strain behaviors in strain jump tests are exhibited in Fig. 5. In the cold rolled $\mathrm{Zr}-1.5 \mathrm{Nb}-\mathrm{O}-$ $\mathrm{S}$, stress jumps were observed during the strain rate jump from $10^{-4} / \mathrm{sec}$ to $10^{-2} / \mathrm{sec}$. The activation volume for plastic

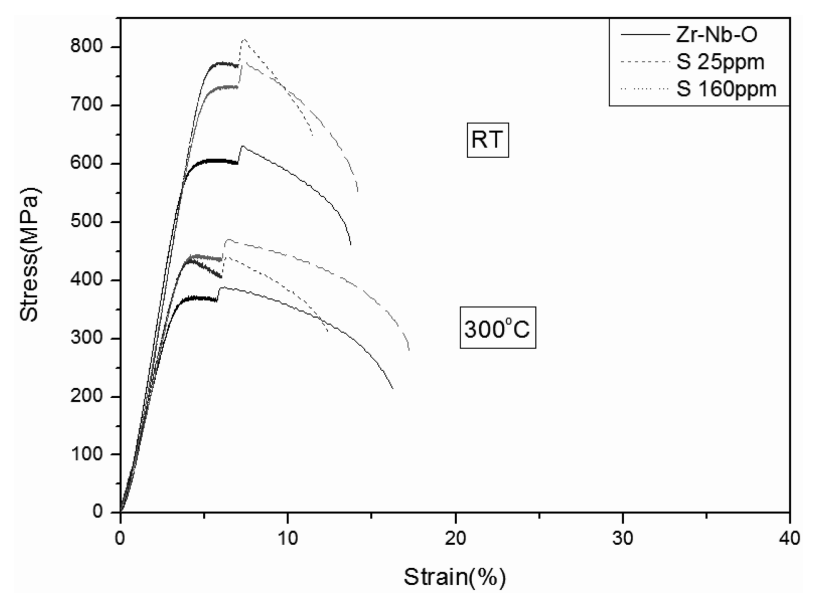

Fig. 5. Stress strain responses during the strain rate jump from $1 \times 10^{-4} / \mathrm{sec}$ to $1 \times 10^{-2} / \mathrm{sec}$ in the cold rolled $\mathrm{Zr}-1.5 \mathrm{Nb}-\mathrm{O}$ and $\mathrm{Zr}-$ $1.5 \mathrm{Nb}-\mathrm{O}-\mathrm{S}$ alloys at the strain rate of $1 \times 10^{-4} / \mathrm{sec}$ at room temperature and $300^{\circ} \mathrm{C}$.

flow was measured by analyzing the transient behaviors during the jump tests and the effect of sulfur on the activation volume for deformation of $\mathrm{Zr}-1.5 \mathrm{Nb}-\mathrm{O}$ alloys was examined. The activation volume $\mathbf{V}^{*}$ associated with the deformation process has been obtained from the following equation: ${ }^{14}$

$$
\mathbf{V}^{*}=\mathrm{kT} \partial \ln \gamma^{*} / \partial \tau=\mathrm{nk} \ln \left({ }^{*} \varepsilon_{1} / \varepsilon_{2}^{*}\right) /\left(\sigma_{1}-\sigma_{2}\right)
$$

where $\mathrm{k}$ is the Boltzmann constant, $\gamma^{*}$ is the shear strain rate, $\sigma_{1}$ and $\sigma_{2}$ are the applied shear stresses at the normal strain rates $\varepsilon_{1}^{*}$ and $\varepsilon_{2}^{*}$ and $\mathrm{T}$ is the absolute temperature. The shear stress $\tau$ was calculated from the normal flow stress $\sigma$, using the relation $\tau=\sigma / \mathrm{m}$, where $\mathrm{m}$ is the Taylor factor. According to Luton and Jonas, $\mathrm{m}$ is assumed to be equal to $4 .^{15)}$ The activation volume and the strain rate sensitivity for the cold rolled $\mathrm{Zr}-\mathrm{Nb}-\mathrm{O}$ and $\mathrm{Zr}-\mathrm{Nb}-\mathrm{O}-\mathrm{S}$ alloys are summarized in Table 2 . The activation volume, $\mathbf{V}^{*}$, decreased slightly with the increase of sulfur content at room temperature and $300^{\circ} \mathrm{C}$.

The sulphur strengthening may arise from the disturbing effects on dislocation motion. The most important factors affecting dislocation motion in solution are the size factor,

Table 2. Activation volume and strain rate sensitivity of $\mathrm{Zr}-1.5 \mathrm{Nb}-\mathrm{O}$ and $\mathrm{Zr}-1.5 \mathrm{Nb}-\mathrm{O}-\mathrm{P}$ alloys at room temperature and $300^{\circ} \mathrm{C}$.

\begin{tabular}{|c|c|c|c|c|c|}
\hline \multirow{2}{*}{ Heat treatment } & \multirow{2}{*}{ Alloy Composition } & \multicolumn{2}{|c|}{ RT } & \multicolumn{2}{|c|}{$300^{\circ} \mathrm{C}$} \\
\hline & & $\mathrm{m}$ & $\mathbf{V}^{*}$ & $\mathrm{~m}$ & $\mathbf{V}^{*}$ \\
\hline \multirow{3}{*}{ Annealed } & $\mathrm{Zr}-1.5 \mathrm{Nb}-\mathrm{O}$ & 0.0204 & $65 \mathrm{~b}^{3}$ & 0.0185 & $266 b^{3}$ \\
\hline & $\mathrm{Zr}-1.5 \mathrm{Nb}-\mathrm{O}-25 \mathrm{ppm} \mathrm{S}$ & 0.0204 & $60 \mathrm{~b}^{3}$ & 0.0187 & $252 b^{3}$ \\
\hline & $\mathrm{Zr}-1.5 \mathrm{Nb}-\mathrm{O}-160 \mathrm{ppm} \mathrm{S}$ & 0.0214 & $47 \mathrm{~b}^{3}$ & 0.0254 & $156 b^{3}$ \\
\hline \multirow{3}{*}{ Cold-Rolled } & $\mathrm{Zr}-1.5 \mathrm{Nb}-\mathrm{O}$ & 0.0106 & $78 \mathrm{~b}^{3}$ & 0.0145 & $182 b^{3}$ \\
\hline & $\mathrm{Zr}-1.5 \mathrm{Nb}-\mathrm{O}-20 \mathrm{ppm} \mathrm{S}$ & 0.0109 & $58 \mathrm{~b}^{3}$ & 0.0168 & $141 b^{3}$ \\
\hline & $\mathrm{Zr}-1.5 \mathrm{Nb}-\mathrm{O}-160 \mathrm{ppm} \mathrm{S}$ & 0.0106 & $52 \mathrm{~b}^{3}$ & 0.0149 & $147 b^{3}$ \\
\hline
\end{tabular}


the modulus factor and the electronic factor. ${ }^{16,17)}$ Morinaga and Kamado $^{18)}$ found that both solution hardening and precipitation hardening can best be predicted by the size difference and the electronegativity difference between the matrix and solute atoms. One interesting observation is that the strengthening effect of sulphur and oxygen are interdependent and sulphur amplified the strengthening effect of oxygen

Some solute atoms such as $\mathrm{Si}$ and $\mathrm{Al}$ are known to amplify the dynamic strain aging effect due to interstitial atoms including oxygen in Ti alloys by enhancing the lattice distortion although they cannot cause the dynamic strain aging directly at intermediate temperatures. ${ }^{19,20)}$ Ferrer et al. ${ }^{6}$ observed that sulphur amplified many dynamic strain aging effects reputed to be due to oxygen, the yield stress plateau, the strain rate sensitivity and ductility minimum, and the static aging peak. Despite the observations indicative of the amplication effect of sulfur on the dynamic
RT
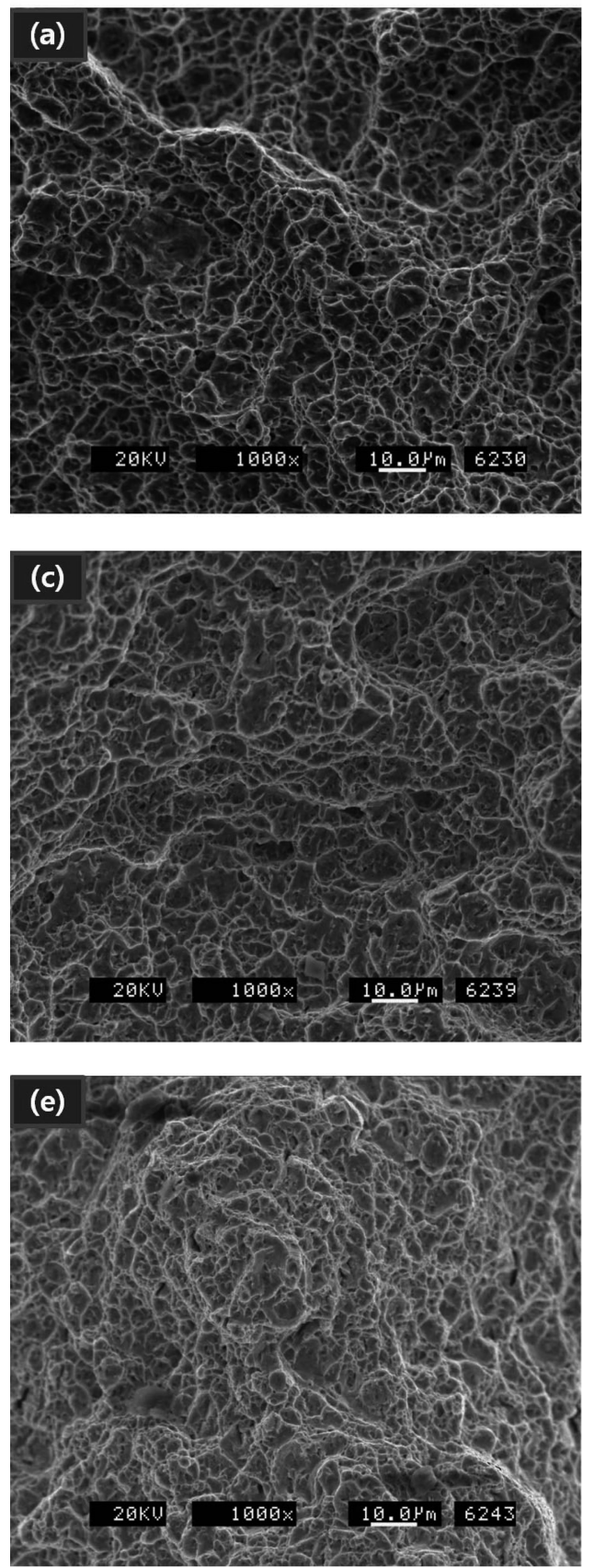

$300^{\circ} \mathrm{C}$
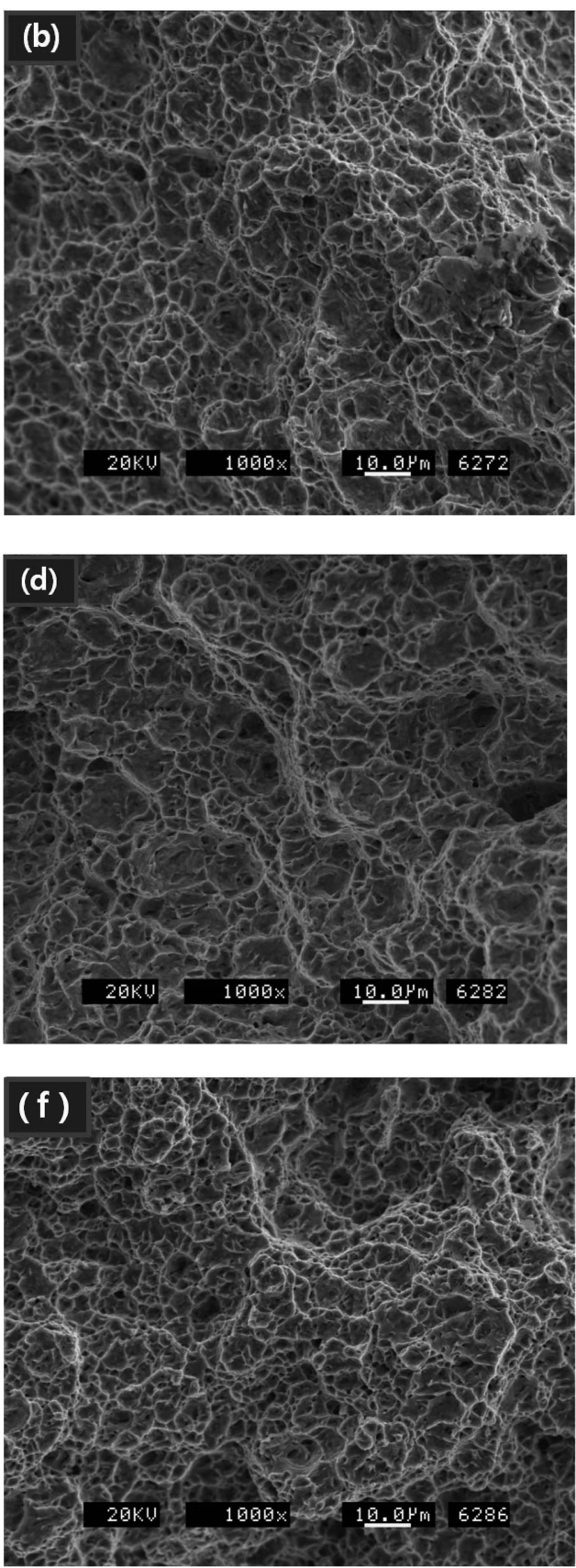

Fig. 6. Fracture surfaces of $\mathrm{Zr}-1.5 \mathrm{Nb}-\mathrm{O}$ (a, d), Zr-1.5Nb-O-25 ppm S (b. e) and Zr-1.5Nb-O-160 ppm S (c. f) after tensile testing at room temperature $(\mathrm{a}, \mathrm{b}, \mathrm{c})$ and $300^{\circ} \mathrm{C}(\mathrm{d}, \mathrm{e}, \mathrm{f})$ are displayed in Fig. $6(\mathrm{a}-\mathrm{f})$. 
strain aging due to oxygen atoms, Ferrer et al. ${ }^{6}$ suggested the sulfur and oxygen effects are independent based on their observation that sulfur strengthening effect remained unchanged in the strain rate and temperature region in which dynamic strain aging due to oxygen disappeared. One important point overlooked by Ferrer et al. ${ }^{12)}$ is that oxygen strengthening consists of two terms, typical solution strengthening and strengthening due to dynamic strain aging. Even in the temperature and strain rate region in which dynamic strain aging effect is negligible, oxygen still strengthen the $\mathrm{Zr}$ matrix through regular solution strengthening. Some alloying elements could also have both independent strengthening effect as well as interdependent strengthening effect.

The segregation of sulphur atoms in addition to oxygen atoms ${ }^{21,22)}$ could decrease the activation volume by limiting the length of the activated bulge and enhance the strengthening effect. Insensitivity of the activation volume to the dislocation density and the decrease of the activation volume at a higher temperature where the dynamic strain aging occurs support the suggestion linking the activation volume with the activated bulge of dislocations limited by segregation of oxygen and sulphur atoms. Dislocations can collect a significant number of solute atoms from its surroundings after being stopped by forest dislocations $^{9,21)}$ even at low temperatures.

Ferrer et al. ${ }^{6}$ ) suggested that sulphur segregation at dislocation core could modify the core structure of dislocations, which would affect most of the dislocation properties including Peierls friction, cross slip, pipe diffusion and interaction with other impurities. However, for the modification of dislocation cores by sulphur to be an operative strengthening mechanism, the dislocation cores should be modified over a reasonable length of dislocations with the modified core structure maintained while they are in motion during deformation. It is questionable if the mobility of sulphur atoms is high enough to keep up with moving dislocations to maintain the modified dislocation core structure during deformation. In Ferrer's model, if the dislocations are liberated from the segregated sulphur atoms, the modified core structure would return to its original structure and the Peierls friction may not be appreciable. Chang and $\mathrm{Hong}^{7)}$ suggested that the ratecontrolling mechanism for the deformation of $\mathrm{Zr}-1.5 \mathrm{Nb}-\mathrm{O}$ and $\mathrm{Zr}-1.5 \mathrm{Nb}-\mathrm{O}-\mathrm{S}$ alloys can best be explained by the dislocation interaction mechanism in which the segregation of alloying elements which affects the activation length of dislocations. ${ }^{9)}$

The strengthening due to sulfur may arise from the disturbing effects of solute atoms on dislocation motion. The most important factors affecting dislocation motion in solution solution are the size factor, the modulus factor and the electronic factor. ${ }^{16,17)}$ Morinaga and Kamado ${ }^{18)}$ found that both solution hardening and precipitation hardening can best be predicted by the size difference and the electronegativity difference between the matrix and solute atoms. The atomic radius of sulfur is $0.106 \mathrm{~nm}$ and that of zirconium is 0.159 , implying that the size factor have a great influence. Since the electronegativity of sulfur and zirconium are 2.58 and 1.33 respectively, ${ }^{23)}$ the electronegativity difference between $\mathrm{Zr}$ and $\mathrm{S}$ is 1.25 and therefore, the electrostatic interaction due to the dipole creation between solute atoms and dislocation would be appreciable. The significant effect of sulfur on the strengthening can be ascribed to the size misfit and the electronegativity difference between zirconium and sulfur.

Fracture surfaces of $\mathrm{Zr}-1.5 \mathrm{Nb}-\mathrm{O}(\mathrm{a}, \mathrm{d}), \mathrm{Zr}-1.5 \mathrm{Nb}-\mathrm{O}-$ $25 \mathrm{ppm} \mathrm{S}$ (b. e) and Zr-1.5Nb-O-160 ppm S (c. f) after tensile testing at room temperature $(\mathrm{a}, \mathrm{b}, \mathrm{c})$ and $300^{\circ} \mathrm{C}$ are displayed in Fig. 6 (a-f). All alloys exhibited ductile fracture surfaces and no groove- or cleavage-like features ${ }^{11)}$ were observed, suggesting no significant detrimental effect of sulfur in fracture of $\mathrm{Zr}-\mathrm{Nb}-\mathrm{O}$ alloys. Fig. 4(d) shows the fracture surface of $\mathrm{Zr}-\mathrm{Nb}-\mathrm{O}-160 \mathrm{ppm} \mathrm{S}$ at $300^{\circ} \mathrm{C}$ and no secondary cracks were observed. The similar ductile fracture surfaces were observed at $300^{\circ} \mathrm{C}$ for $\mathrm{Zr}-\mathrm{Nb}$ and $\mathrm{Zr}$ $\mathrm{Nb}-20 \mathrm{ppm} \mathrm{S}$. The absence of groove- or cleavage-like features on the fracture surface is compatible with the observation that $\mathrm{Zr}-\mathrm{Nb}$ alloys with $20 \mathrm{ppm}$ phosphorous addition have no sulfide particles which may act as fracture paths as in Ti alloys. ${ }^{24)}$

In Fig. 7, the oxidation behavior of $\mathrm{Zr}-1.5 \mathrm{Nb}-\mathrm{O}, \mathrm{Zr}-$ $1.5 \mathrm{Nb}-\mathrm{O}-25 \mathrm{ppm} \mathrm{S}$ and $\mathrm{Zr}-1.5 \mathrm{Nb}-\mathrm{O}-160 \mathrm{ppm} \mathrm{S}$ at $300^{\circ} \mathrm{C}$ in air are shown. The weight gain due to oxide formation was observed to decrease with the addition of sulfur. Charquet $^{11)}$ found that the addition of even small amount of sulfur markedly improve the steam corrosion resistance, particularly in the range between 2 and $200 \mathrm{ppm}$. The

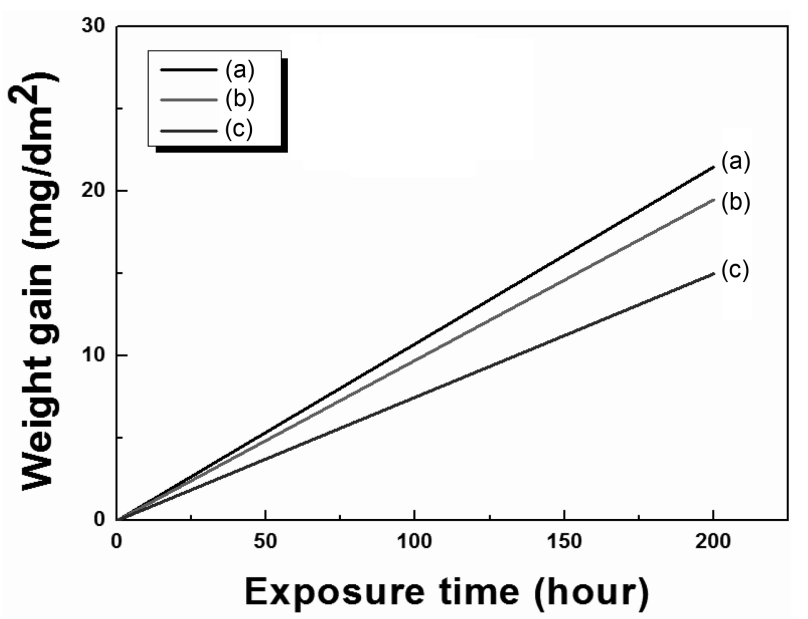

Fig. 7. The oxidation behavior of (a) $\mathrm{Zr}-1.5 \mathrm{Nb}-\mathrm{O}$, (b) $\mathrm{Zr}-1.5 \mathrm{Nb}-\mathrm{O}-$ $25 \mathrm{ppm} \mathrm{S}$ and (c) $\mathrm{Zr}-1.5 \mathrm{Nb}-\mathrm{O}-160 \mathrm{ppm} \mathrm{S}$ in air at $300^{\circ} \mathrm{C}$. 
beneficial influence of the sulfur content was observed whatever its metallurgical state: in solid solution and mainly as sulfides. When there were sulfides the key factor is probably the volume fraction of precipitates. However, the reason for the beneficial influence of sulfur was not understood, yet. The sulfur may influence the phase and structural stability of oxide, which remains to be solved in the future work. ${ }^{25)}$

\section{Conclusion}

On the basis of the investigation of mechanical and oxidation properties of $\mathrm{Zr}-1.5 \mathrm{Nb}-\mathrm{O}-\mathrm{S}$ alloys, the following conclusions can be drawn:

1. The yield strengths of $\mathrm{Zr}-1.5 \mathrm{Nb}-\mathrm{O}-\mathrm{S}$ alloy with $160 \mathrm{ppm}$ sulfur $(740 \mathrm{MPa})$ were higher than that of $\mathrm{Zr}$ $1 \mathrm{Nb}-1 \mathrm{Sn}-0.1 \mathrm{Fe}$ alloy $(730 \mathrm{MPa})$, achieving higher strength than $\mathrm{Zr}-1 \mathrm{Nb}-1 \mathrm{Sn}-0.1 \mathrm{Fe}$ alloy even after the elimination of $\mathrm{Sn}$, an effective solution hardening alloying element. The ductility of $\mathrm{Zr}-1.5 \mathrm{Nb}-\mathrm{O}-\mathrm{S}$ was found to be higher compared to that of commercially available $\mathrm{Zr}-1 \mathrm{Nb}-1 \mathrm{Sn}-0.1 \mathrm{Fe}$.

2. The beneficial effect of sulfur on the strengthening was observed in the cold rolled $\mathrm{Zr}-1.5 \mathrm{Nb}-\mathrm{O}-\mathrm{S}$ alloys over the wide temperature range from room temperature up to $300^{\circ} \mathrm{C}$ in the cold rolled $\mathrm{Zr}-1.5 \mathrm{Nb}-\mathrm{O}-\mathrm{S}$.

3. The dynamic strain aging effect in the cold rolled $\mathrm{Zr}-1.5 \mathrm{Nb}-\mathrm{O}-\mathrm{S}$ is less clear because the strengthening due to the dynamic interaction between oxygen/sulphur atoms and dislocation is relatively small compared to the substructure strengthening due to the high dislocation density stored during cold rolling. The detrimental effect of phosphorous on the ductility in the cold rolled $\mathrm{Zr}$ $1.5 \mathrm{Nb}-\mathrm{O}-\mathrm{S}$ is less pronounced.

4. The activation volumes, $\mathbf{V}^{*}$, for the cold rolled $\mathrm{Zr}$ $1.5 \mathrm{Nb}$ decreased slightly with the increase of sulphur content at room temperature and $300^{\circ} \mathrm{C}$. The rate-controlling mechanism of the deformation can be explained by the dislocation interaction mechanism in which the segregation of oxygen and sulphur atoms affects the activation length of dislocations.

5. Fracture surfaces of $\mathrm{Zr}-1.5 \mathrm{Nb}-\mathrm{O}$ and $\mathrm{Zr}-1.5 \mathrm{Nb}-\mathrm{O}-\mathrm{S}$ alloys exhibited ductile fracture and no groove- or cleavage-like features were observed, suggesting no significant detrimental effect of sulfur in fracture of $\mathrm{Zr}$ $1.5 \mathrm{Nb}-\mathrm{O}$ alloys.

6. The weight gain due to oxide formation was observed to decrease with the addition of sulfur. In compatible with the observation of Charquet that the addition of even small amount of sulfur markedly improve the steam corrosion resistance, particularly in the range between 2 and 200 ppm.

\section{Acknowledgements}

This research was supported by Basic Atomic Energy Research Institute Program through the National Research Foundation of Korea (NRF) funded by the Ministry of Education, Science and Technology (2009-0075917).

\section{References}

1. J. A. L. Robertson, J. Nucl. Mater., 100, 108 (1981).

2. E. Tenckhoff and P. L. Rittenhouse, J. Nucl. Mater., 35, 14 (1970).

3. E. F Ibrahim, R. Choubey and J. J. Jonas, J. Nucl. Mater., 126, 44 (1984).

4. R. A. Holt, J. Nucl. Mater., 159, 310 (1988).

5. W. Liu, Q. Li, B. Zhou, Q. Yan and M. Yao, J. Nucl. Mater., 341, 97 (2005).

6. D. Charquet, J. Senevat and J. P. Marcon, J. Nucl. Mater., 255, 78 (1998).

7. K. I. Chang and S. I. Hong, J. Nucl. Mater., 373, 16 (2008).

8. A. J. Stewart and M.W. Schmidt, Geophys. Res. Lett., 34, L13201 (2007).

9. D. Bika and C. J. McMahon Jr., Acta Metall. Mater., 43, 1909 (1995).

10. R. Wu, A. J. Freeman and G. B. Olson, Science, 265, 376 (1994).

11. D. Charquet, J. Nucl. Mater., 304, 246 (2002).

12. F. Ferrer, A. Barbu, T. Bretheau, J. Crepin, F. Willaime and D. Charquet, p. 863, Thirteenth International Symposium on Zirconium in the Nuclear Industry, ASTM STP 1423, ASTM International, West Conshohocken, USA (2002).

13. S. Ko, S. I. Hong and K. T. Kim, J. Nucl. Mater., 404, 154 (2010)

14. H. Conrad, J. Met., 16, 582 (1964).

15. M. J. Luton and J. J. Jonas, Can. Metall. Q., 11, 79 (1972).

16. R. L. Fleisgher, Acta Metall., 11, 203 (1963).

17. R. L. Fleisgher, Acta Metall., 9, 996 (1961).

18. M. Morinaga and S. Kamado, Model. Simulat. Mater. Sci. Eng., 1, 151 (1993).

19. S. I. Hong, W. S. Ryu and C. S. Rim, J. Nucl. Mater., 116, 314 (1983).

20. S. I. Hong, Mater. Sci. Eng., 64, L19 (1984).

21. Z. S. Basinski, R. A. Foxall and R. Pascual, Scripta Metall., 6, 807 (1972).

22. S. I. Hong and C. Laird, Acta Metall. Mater., 38, 1581 (1990).

23. S. Ege, Organic Chemistry, 5th ed., p.27, Houghton Miffin Harcourt, Boston, USA (2003).

24. D. Hu, A. J. Huang, X. P. Song and X. Wu, J. Alloy Comp., 413, 77 (2006).

25. S. M. Seo, K. S. Lee and K. A. Lee, Kor. J. Mater. Res., 14(3), 163 (2004) (in Korean). 